\title{
CONFLICTING RELIGIOUS IDENTITIES: BLASPHEMING ISLAM AND THE FUTURE OF DEMOCRACY IN INDONESIA
}

\author{
Saipul Hamdi ${ }^{1}$ \\ Politektik Pertanian Negeri Samarinda \\ Email: hamdiugm@gmail.com
}

\begin{abstract}
The paper explores the phenomena of conflicting religious identities among Indonesian politicians in Jakarta's regional election (pilkada) in 2017. The 2017 most dramatized Jakarta regional election has been seen as a very important political phenomenon in recent time as it revealed the conflicting social-political identity construction across religious and ethnic groups in the region. This work attempts to provide explanation from the perspective of religious studies on the roles of religious identities in the political realm as well as religioous and political symbols as tools to achieve political supports. The case of Ahok mentioning one of the Quranic verses of al-Maidah 51 in Kepulauan Seribu exposes the fundamental question of wheter it is apart of blaspheming Islam and insulting ulama. It also shows how the Islamist groups respond to it by using the case of the politicizing al-Maidah 51 to reduce Ahok electability and disqualify him from political contestation by accusing him to blaspheme Islam. The complexity of applying Quranic texts to the modern political platform brings this article to outline how Muslim scholars interpret al-Maidah 51 and how they situate the text into the context of modern politics in Indonesia as well as how it influences the future of Indonesian democracy.
\end{abstract}

Keywords: Religious identities, blasphemy, al-Maidah 51, Indonesia and democracy

\section{INTRODUCTION}

Religious identities play a pivotal role in the contemporary Indonesian politic landscape since the fall of the Suharto regime in 1998, which has been marked by reinforcement of Islamist political movement. For three decades after taking over the country rule in the early 1970s, Suharto regime has

${ }^{1}$ The author would like to aknowledge the support by Politeknik Negeri Samarinda for this research-based article and expresses his deepest grattitute. It is also the intention of the author to credit the Annual International Conference on Islamic Studies (AICIS) 2017 organized by the Ministry of Religious Affair of the Republic of Indonesia in which the author was invited to present the paper. It was held in Jakarta on 22-25 November 2017 
controlled Indonesian politics over Indonesian archipelagos and strained opposition resistance including Islamist faction (Assyaukanie, 2013; Aspinal, 2005; Hamdi, Carnegie, \& Smith, 2015). Ken Miichi (2006: 129) describes this strategy to disempower Islamist political movement and reactivates them as a puppet for encountering socio-political critics of human right violation and unsecured freedom. Since the New Orde's fall, a new politics system has been constructed after a national reformation movement took place in 1998 lead by Muslim activists, lecturers and students. This political situation has provided open space for freedom and new democracy. In this new freedom all politic wings grow rapidly including the Islamist groups where they take advantage to strengthen and re-expand their political wings through parliament and nonparliament. The rise of Islamist movements takes us back to similar situation in early independent 1950s, in which they focus on upholding syariah campaign like what Masyumi party strugled. In addition to that, the extremist group of Darul Islam and Indonesian Islamic Army (DI/TII) had struggled to reinstall Islamic state system (khilafah Islamiyah) instead of secular state of Pancasila (Effendey: 2003: 2: Platzdasch, 2009: 2).

The new era of Indonesian politics has been marked by reformation on political system and government bureaucracy followed by the assurance of civil rights and freedom, and equality (Hamdi, 2011). As I mention earlier, Islamist groups take part in contemporary politics contestation either in parliament or non-parliament. Prosperous Justice Party (Partai Keadilan Sejahtera) is representing the fundamentalist Muslim voice in parliament. Together with Crescent Star Party (Partai Bulan Bintang), PKS carries a great Islamic agenda in re-upholding sharia as Indonesian official law replacing secular law (Platzdasch, 2009: 337; Buehler, 2009: 59). From its political platform, PKS has been inspired a lot by Islamic fundamentalist party Ikwhanul Muslimin in Egypt through Al-Azhar University alumni, however it has transformed to a local politics and culture stetting of Indonesia. PKS has a solid constituent around $8.19 \%$ voters in 2004 and 6.79\% in 2014 (Bawazir, 2015:210). PKS also runs education institution to regenerate young intellectual as well as young politicians. Most Islamist members from HTI, FPI, Muhammadiyah have affiliated to PKS party as supporters, even in some ways they have different approach to actualize Islamic state agenda.

The article examines the role of Islamist groups in regional election politic of Indonesian capital Jakarta 2017, and the way they conflicted religious and ethnic identities. Politicizing religious and ethnic identities commonly occur as a propaganda strategy to win political contestation. The phenomenon of Jakarta regional election 2017 shows how religion and ethnic identities 
have been played by the Islamist groups to resist and challenge non-Muslim leadership. They clearly use religion especially al-Maidah 51 to refuse a nonMuslim leader by arguing that Islam has banned appointing a leader from non-Muslim in the majority of Islamic community (Lim, 2017:3; Hadiz, 2018: 262). The Islamist figures such as Habib Rizieq, Al-khattat and Amin Rais rise up this issue by mobilizing mass for demonstration even demanded Ahok to fall down for his status as governor and stop him to be candidate in the next election. In response to the pressures from Islamist groups, Ahok accidently mentioned al-Maidah 51 in his formal speech in Kepulauan Seribu said, "alMaidah 51 has been used by politicians to cheat other Muslim to support their political agenda, so do not want to be cheated by using al-Maidah 51 and so on, even you do not vote me do not worry, this project keeps continue until my contract finish". This statement generates controversy and political drama after his video was cut and circulated by Buni Yani on YouTube. Yani put transcript and take off some word to stimulate anger emotion from Muslim community across Indonesia.

Yani was successful accusing Ahok for blaspheming Islam and stimulating Muslim activist to a demonstration. Muslim activist come down to street protesting Ahok with the largest mass mobilization. Looking at this wild issue, his political opponents together with Islamist groups took advantage to carry this case into politics domain as religious capitalization of Jakarta election. The Islamist group accuses Ahok for blaspheming Quran and insulting ulema and this is the only way to defeat him in this regional election contestation. Therefore, Islamist groups give pressure to Indonesian police and president to detain him by mobilizing insistently the largest demonstration in Indonesian history called "the peace action of defending Islam 411 and 212". They also warn the government, who are politically in coalition with Ahok, never protect and has to detain him. The government considers the Muslim voices by carrying this case to the state court in order to avoid Muslim revolution and violence action. After Indonesian Ulema Council release an attitude toward Ahok statement as part of blasphemy, the police put this case officially to the court (Lim, 2017: 4). How Muslim scholars respond to blasphemy accusation and how they interpret al-Maidah 51 will explore in next discussion. This case has been tremendous effect to Ahok politics career as minority, where he defeated for the second term and charged for penalty during two years in jail after the election. I believe that phsycological deminsion is also important in the case of convlict including religious groups (Lingren, 2016). For the latest, the deeper studies on the Ahok case is indeed needed as an addional to this work. 


\section{THE ANTI BLASPHEMY LAW AND POLITICIZING THE SACRED TEXT}

Blasphemy cases on religion usually remain a big question and a social controversy not only in Indonesia, but also around the world. From human rights perspective, blasphemy transgresses the basic values of democracy in which provide freedom and equal right for all the people delivering critics and argument through writing and talking about socio-political phenomena including justice and religious symbol (Gubo, 2015:2-3). However, it was misunderstood and confused regarding the different element between insulting and critics to the sacred thing or symbol. If there is a new interpretation of the sacred text coming up deviates from orthodox discourse and understanding, it will be excluded, judged and accused for conducting blasphemy. Some have shown that because they have different interpretation of the sacred text to majority understanding, they have been called as "deviant".

Blasphemy is defined as the act of insulting or showing contempt to a deity, holy person and sacred things. Some religions in the world consider blasphemy as religious crime and there are anti-blasphemy law in 32 countries and hate speech laws in 87 countries that cover defamation of religion and public expression of hate against a religious group (Gubo, 2015: 4). Blasphemy law is common in Muslim majority nations such as those in the Middle East and North Africa, although they also present in Asia and some European countries. In the United Nations, blasphemy has become a critical issue for the 21 st century, when Islamic countries did a massive campaign for worldwide criminal penalties for the 'defamation of religions'. However, the campaign ended in 2011 when the proposal withdrawn in Geneva, in the human rights council because of lack support (Council of Europe, 2010: 11).

Anti-blasphemy law in Indonesia is part of colonial inheritance law. Originally it is not related to religious defamation, rather than protection law for the Dutch people from local resistance following challenges toward colonial authority. However, 1965 Sukarno has been repressed by conservative Muslim groups to develop anti-blasphemy law from the Dutch law for the protection of religious purity and reduction of religious deviance (heresy) practices. Sukarno gave attention to the conservative voices due to the vulnerability of religion under the significant proliferation of spiritual movements (aliran kepercayaan) across Indonesian islands, that able generate a negative effect to fundamental structure of Islamic religiosity. In response to the demand of conservative

${ }^{2}$ See the wokk by Prasojo (2017) for the case of ethnic and religious group relation in West Kalimantan consisting of Tionghua, Dayak and Malay. See also the works by Ernas (2016) and Rumahuru (2016) for the case of inter-religious relation in Ambon consisting of Muslim and Christian. 
voices Sukarno creates Presidential Decree No. 1/PNPS/1965 anti-blasphemy law that consist of two articles 156 and 156a. However, the anti- blasphemy often abused to repress and disempower the minority group; even now it is used for achieving political interest including in regional elections process (Crouch, 2012: 2; Legal, 2017: 4).

Suharto transformed Presidential Decree 1965 of religious blasphemy to be official constitution or Undang-undang No. 09/1969 to prevent social dispute and protect the state stability. Indeed, Suharto often abused the blasphemy constitution, especially the article 165 and 165a to protect his regime authority from critics and resistances. In several cases, Suharto applied an aggressive policy attacking Muslim activist, including Tanjung Priok case 1984, where military member shoot demonstrators in Tanjung Priok harbor. This precedent started by activists who protested upon apprehension of their colleagues after little dispute with military member who come in to the mosque without taking his shoes.

Blasphemy becomes national debate after Ahok statement accused as insulting ulema and the Quran. It attracted national attention because Ahok is governor of Indonesian capital and one of the most controversial leaders in contemporary Indonesian politic. His reformation agenda for a clean and professional government inflicts cultural shock not only for the staffs, but also for the communities, who are not ready to accept his idea of changes and transformations. So, I argue that this blasphemy case is a big design to fall him dawn as governor and dissuades him for the next election. Far away before the regional election takes place in Jakarta, Islamist groups especially FPI has been protested to his inauguration as governor after Jokowi jumps to president chair. By carrying religious and ethnic identities as legitimacy to disempower Ahok authority and delegitimize a non-Muslim leadership is the only way to get him dawn (Hadiz, 2018: 263).

Blasphemy is a key to reduce Ahok electability that four month before has reached over $60 \%$. Even he did not mention al-Maidah 51 for instants, he already accused to blaspheme Islam because he is not Muslim and banned to be leader in the majority of Islamic community base on al-Maidah 51. Defamation issue has taken place for a long time since he became mayor in East Belitung and governor candidate in the Banka Belitung province in regional election 2007 (Ginting, 2008: 40). Another fact shows that Ahok has been defied by Islamist groups in Jakarta when he accompanied Jokowi in the previous Jakarta election 2012. Al-Maidah 51 has been spread out to ignore Ahok and Jokowi duet due to his different religiosity and ethnicity. For a decade, al-Maidah 51 becomes a political verse in several regional elections 
that often appears during the campaign process and disappears in the end of the election(Hadiz, 2018: 264).

During regional election of Jakarta, the Islamist groups use blasphemy issue as demonstration moment. The largest mass mobilization called 411 and 212 in 2016 presented by Muslim across Indonesian archipelago. Around 1 million people down to street for a long march from Istiqlal mosque to the National Monument, Bundaran HI, then to president palace demanding Jokowi to detain Ahok. The movement of 411 was attended by some religious figures, artists and politicians, including A. A Gym, Fadly Zon, Fahri Hamzah, Ahmad Dani, and Amin Rais. Politically, those figures are opposition to Jokowi's government, where they come from a different political party. At that demonstration protesters appeal a meeting with Jokowi to discuss about Ahok case, but no response from him and he chooses to leave the palace and ignore those demands. Because they failed to see Jokowi those protesters attack the police and make chaos and violence. There are groups of motorbike gangster in many spot around demonstration area goes to robbery targeting Chinese stores. The same schema in the following demonstration action called 212, presented by mass around 700.000-1.5 million people. At this time, Jokowi and Yusuf Kala decide to see those demonstrators and give a short speech to calm down their emotional and appreciate the peace commitment for demonstration process(Lim, 2017:3).

Under a strong pressure finally Ahok delivers a deep sorry through media for his mistaken statement in Kepulauan Seribu. He explains that he has no aim to insult ulame or blaspheme the Quran, it is a pure critic to Muslim politician who often abuse the Quran as weapon of politics goal. Ahok emphasizes that there are some politicians play this issue to disqualify him for the next Jakarta election. It is not making sense for me to blaspheme Islamic symbol, while the majority of my supporters are Muslim, Ahok said. He shows his effort to help Muslim people to Mekkah for hajj and build religious facilities such as mosques. After the police carried this case to official court it influences his electability. Ahok has to undergo the blasphemy trial in the court during his campaign time and face horrified experience in the field. Anywhere he and the team socialize his program during the campaign; he has been refused and attacked by certain group systematically.

\section{THE VERSE OF PILKADA: CHALLENGING AN ORTHODOX INTERPRETATION}

Ahok is a new phenomenon of Indonesian modern politician leader together with Jokowi, promoting mental revolution and anti-corruption. They have 
strong chemistry as politician pairs where Jokowi is well known with his downto-earth character, hard worker, and close to people, while Ahok is assertive, reasonable, and professional (Hamid, 2012: 335; Prasetyo, 2014: 3; Mulyadi, 2016: 130). Jokowi encourages respecting plurality and diversity as well as equality rights among Indonesian, including the engagement for minority group in country development process. His political approach made Jokowi as one of young successful leaders in contemporary Indonesian politics. In 2010, Jokowi-and FX Hadi Rudyatmo reach $90.09 \%$ voters for the second election term in Solo. No resistance from Islamist group regarding Jokowi's politics step in Solo engaging non-Muslim politician as vice mayor (Prasetyo, 2014: 8). Different situation in Jakarta election, he experiences a serious challenge from Islamist groups that rejected his idea choosing a Christian politic background. Ahok is becoming an object for religious critics refer to textual interpretation of al-Maidah 51.

Even there is a strong ignorance of Ahok status, the Islamist groups cannot override him from governor chair following the Indonesian constitution. However, the engagement of Islamist political domain has generated a socialpolitical drama not only in Jakarta election, but also in all over Indonesian archipelagos as the result of media exposure. The battle of political ideology and religious identity extremely happens when Ahok replaces Jokowi as governor after winning the presidential election in 2014. During the presidential election campaign, Jokowi also experiences the attack through social media, where they were questioning his religious and ethnic identities. They accused him as a Christian and Chinese decedent blood. The rumor has been outbreak to Jokowi family's political identity that indicates partisan of Indonesian Communist Party member in 1960s. At the same time Islamist group continue to challenge Ahok new status as governor by mobilization of militia to stop his inauguration by president (Lim, 2017: 4).

In order to understand the reason why Islamist groups were challenging Ahok authority and accusing blasphemy, we need to explore the way they understand and interpret al-Maidah 51. Al-Maidah 51 has been public discourse and national debate not only related to its contents, but also its interpretation when it was connected to contemporary context of Indonesian politics and its compatibility in implementation in the new democracy system. This verse unfolds the controversy and more complex question in modern politics era especially in the plural community, where Muslim is minority group. It is potential to politicize for achieving political interest by certain group of Muslim who used to stand behind the Quran. In fact, al-Maidah 51 is well known special verse of Pilkada, which often appears when the regional election 
event comes and disappears when it finish. In doing so, this article examines the plurality of al-Maidah 51 interpretations among Muslims scholars and how they contextualize it in modern democracy (Lim, 2017:6-7).

Ahok was blamed for his comment about al-Maidah 51 as assaults the Quran and insults ulama, however he believes it is purely a critic for bad manner of Muslim politician who abusing the Quran to support their political agenda. Ahok tries to challenge the orthodox interpretation of alMaidah 51 by following Gusdur interpretation that opposite to orthodox understanding. Gusdur is a charismatic and a pluralist figure from traditional organization Nahdlatul Ulama, who protect minority group from violence and discrimination. Gusdur is Ahok spiritual teacher and politics advisor since they made contact to collaborate in previous regional election of Banka Belitung, in which PKB party support Ahok. The reason Gusdur assisted him because his achievement program during to be mayor in East Belitung 2005-2006. Al-Maidah 51 has been erupted during the process of political campaign in that regional election, in which directly influence the grade of Ahok electability. Ahok and Eko Cahyono lost in this Pilkada contestation. According to Eko al-Maidah 51 becomes tsunami attack for him and Ahok it was used as a political weapon. Al-Maidah 51 disseminated as religious propaganda refusing on-Muslim leadership. ${ }^{3}$ The Muslim candidate use kyais to spread out this propaganda agitating other Muslims to vote candidate from the same religion. So, what happen was the current case of Ahok in Jakarta is repetition from previous experience.

There are varied interpretations of al-Maidah 51 among Muslim scholars in response to Ahok case. The word aulia in al-Maidah 51 is main objet for the discussion and argument related to the meaning and the connection to the modern political context. Gusdur said, al-Maidah 51 did not relate to leadership matter, rather a critic and warning to the unethical manner from Muhammad friend who want to fracture Islamic community by creating alliance with non-Muslim including the Christians and the Jews. This is the reason why this verse down through to remind Muhammad of his potential internal enemy. According to Gusdur Ahok has no bad intention like what it shows in this verse, on the contrary he made a good relation to Muslim people and has adopted father from Muslim family. He cares upon Muslim necessities even he is Christian leader. He prioritizes all the Muslim needs like building mosque and fellowship for hajj. So, it is wrong to use this verse for targeting

${ }^{3}$ See http://medan.tribunnews.com/2017/03/07/pernah-kalah-saat-jadiduet-cagub-cawagub-ini-kesaksian-eko-cahyono-soal-ahok-yang-mengejutkan?page=2, downloaded in March 7, 2017. 
Ahok in order to achieve the politics interest, Gusdur said.

Nazarudin Umar, a great Imam of Istiqlal mosque and professor in State Islamic University of Syarif Hidayatullah Jakarta re-strengthens Gusdur interpretation on al-Maidah 51. In a special interview by private channel TVOne 2016 Umar states that there are various interpretations of Al-Maidah 51 from Muslim scholars, but no one translates auliya as a leader either in English or Arabic book of interpretation. He said, there are 10 translations of the Quran he had read including English translation by Abdullah Yusuf Ali where he translates auliya as protector, close friends and alliance. Only a translation from Ministry of Religious Affair translates auliya as a leader. In his opinion, it was influenced a misleading of understanding by Muslim about this verse. However, he deplores Ahok statement mentioned al-Maidah 51 that probably was causing a hurt for Muslim. He suggests let Muslim interpret their own sacred text even there are many approaches to understand the meaning of auliya in Al-Maidah 51. He also criticizes the single approach by Islamist interpretation of auliya as a leader, which has socio-political consequences especially for minority groups.

The same opinion by Qurays Shihab, a prominent Muslim scholar for Quranic interpretation said, auliya does not mean a leader in this context, but mean protector, alliance or close friend. Close friend mean the one who has access to the secret matter and the private information like mayor closes to his people; marriage guardian wali nikah closes to his daughter. He illustrates a leader like a pilot, we choose based on capability, not identity. Which one will will choose non-Muslim pilot with a great experience and was a senior or Muslim pilot with a poor experience and still junior. Emha Ainun Najib challenges the Islamist judgment about Ahok as "kafir". According to Najib Ahok is not kafir because he believes in God and admires the truth of Quran, even he criticize his own religious tradition as irrational religion. So, he is not kefir but hypocrite or shirk, Najib said. He also questions the Islamist attitude refusing Ahok as governor candidate of Jakarta in the next election, while he is already our governor now.

Syafi'i Maarif and Mustofa Bisri interpret al-Maidah 51 in a moderate way saying that this verse is not connected directly to leadership matter. They believe no harm for Muslim to vote non-Muslim leader especially in the modern political context if they have ability. The verse of al-Maidah 51 come down in war situation where not allowed to made alliance with enemies because could endanger Muslim itself. So, we cannot use this verse as legitimacy and weapon for politics agenda. They see Ahok statement as deep critics to Muslim politician being unethical, hypocrite and corrupted. They suggest 
forgiving Ahok after him apologies and regret to his comment. Informal Ahok's spokesmen during Jakarta election, Nusron Wahid commented on the blasphemy case of al-Maidah 51 as political trick and strongly connected to Jakarta election. Nothing to do with blasphemy, it just the way to decrees Ahok electability. Nusron argues, Ahok is not the only Christian governor in the Muslim history; it existed since Islamic kingdom era, where some Christian figures sit in a strategic position including as governor. So, he challenges the orthodox interpretation of al-Maidah 51 that no more suitable upon modern political context.

Habib Rizieq, the head of FPI accused those Muslim scholars and ulame who support Ahok leadership as zindiq and hypocrite. Rizieq regrets with their efforts of misleading the real al-Maidah 51 interpretations to fit with their interest. He explains even the meaning of auliyah varies including alliance, close friend, protector, and leader, but it is not fair to take only one meaning to suit politics interest and withdraw others. We need to see the local context base one religious guidance where Jakarta population is the majority of Muslim. He believed, the true meaning of auliya in Indonesian context is "leaders". So, allowing non-Muslim to be a leader in the majority of Muslim community, including as governor is a deviant teaching of Islam. Similar opinion from Yunahar Ilyas, Muhammadiyah scholar said, non-Muslim is prohibited to be leader in a majority Muslim community. Not only al-Maidah 51 clearly discusses about this issue, but also in other verses of Quran that banned non-Muslim leadership. He refers the story of Umar bin Khattab, who was angry upon the attitude governor of Musa Al-Asyari appointing nonMuslim as accountant. Musa al-Asyari was invited for report presentation on his financial administration in front of Umar and the result was good and impressive. Umar asked to see his accountant, but Asyari refuses to take him because he is Christian. He was angry to Al-Asyari because of this issue.

Saik Aqil Husin al-Munawar, ex-ministry of Indonesian religious affair emphasizes the textual meaning of Al-Maidah 51 that clearly has banned nonMuslim (Jews and Christian) to be leader in a majority Muslim community. No need to reinterpret this verse because it has a clear meaning. There is a prohibition word in this text by using proposition "la" in the beginning of sentence which means "no". He understood it had banned not only on leadership matter, but also supporting or asking assistance from both groups. AA Gym, a charismatic cleric from West Java believes that auliya has plural meaning including a leader. For Indonesian context the meaning of auliya more contextual toward leadership because we are the majority group, he said. He expresses his disappointment to Ahok statement that was assaulted Islamic 
values and played sacred symbol. It was really hurt for us, but we have to pray for him to get guidance or hidayah, AA Gym said.

From those different interpretations about al-Maidah 51 above, at least there are two groups have contested the discourses related to Muslim response on leadership status of non-Muslim in majority group. The first group follows orthodox ways using a normative interpretation of the text. They understand the text literally as a reference without considering the current local context. FPI, HTI, FUI, Muhammadiyah, and PKS are part of this group representing the orthodox way; even not all members have the same interpretation, but the majority of them are. The second group is the challenger of orthodox method and promotes heterodox way to contextualize the text to the current socialpolitical reality. This group represented by Nahdlatul Ulama (NU) scholars, the majority of Muslim organization in Indonesia. The young scholars of NU such as Zuhairi Misrawi, Guntur Ramli and Nuron Wahid promotes a new method to understand the text. Their opinion some time creates a social controversy in the society due to negative response from the majority group that used to refer a traditional and orthodox way. Zuhairi Misrawi for instance stated, no significant influence by Ahok statement destroy our belief. So, we cannot accuse him blaspheming Quran and insulting ulame only because of this instant statement. Misrawi said, his statement intend to criticizes the bad behavior of Muslim politician using religious symbol for personal and group interest. Al-Maidah 51 is the verse of war, so it is difficult to apply literally in the new modern Indonesian democracy and politics context. He believes the main reason of anti Ahok rises up this issue only because he is clean, honest and anti-corruption, so no space for them to corrupt.

It is very important to say here that there is misunderstanding upon Ahok thought, especially the way he think and hold his commitment to a clean bureaucracy. Ahok is a very critical thinker and talk philosophical way to analyze the socio-political reality. However, not everybody can accept his way of thinking and uncomfortable to hear deep critics. In addition, Ahok is a brave person to say openly what he wants and refuses things do not make sense. His book about "Mengubah Indoenesia" is representation the way he thinks and applies highly religious ethics in practice for policy making and decision. In that book he already mention al-Maidah 51 base on his experience in the previous regional election of Bangka Belitung 2007, in which he was attacked by this verse during campaign time and make him loss in that regional contestation (Ginting (at.al), 2008). 


\section{THE FUTURE OF INDONESIAN DEMOCRACY}

The future of Indonesian democracy recently is in a serious vulnerability and challenges by the emergence of Islamist groups that play a significant role in the new Indonesian political landscape. In fact, the presence of Islamist group is causing social and political turbulence shaking Indonesian stability by carrying identities of religion and ethnic in conflict. Since they problematize Ahok status as vice governor of Jakarta province 2012 and governor in 2014, the conflict of religious and ethnic identities is stronger and more sensitive especially between Christianity and Islam. This conflict is not purely about religion but more about politics interest and election contestation that carries religious symbol on war. The culmination of this conflict has been visible clearly when the Islamist group challenges Ahok decision as candidate of Jakarta in regional election 2017 with Djarot Saiful Hidayat, who supported by PDIP, Golkar, Nadem and Hanura.

The tension between majority and minority group is sharper after Ahok accused guilty on blasphemy case by state court and had been punished for two years detained. It was a long process since he charged assaulting Islam, Quran and ulame after delivering formal speech, in which follow by the largest religio-politics demonstration called 411 and 212 lead by FPI. This penalty has big impact on social relation stability among Indonesian that put a fractured in national level. Indonesian people including national figures divided and fractured in two groups. Physical and non-physical identity conflicts take place not only in Jakarta, but also in some places where various persecutions happen toward respective fanatic followers. The war is more visible through social media assaulting another figure and praising their own. Ahokers have been persecuted by FPI militia members because they have assaulted the FPI imam, Habib Rizieq, a main actor behind the fall of Ahok authority. The same event takes place upon certain religious figures, which insult and condemns Ahok excessively. MUI members and politicians who are "anti Ahok" had been refused by local community when they visit to other provinces such as Papua, West Kalimantan, Maluku and East Nusa Tenggara, and Bali where non-Muslim is the majority.

The secretary of MUI, Tengku Zulkarnain was attacked right when he come down from the plane in his visit for da'wa in Sintang, Pontianak January 12, 2017. The Dayak community refused his attendance in Pontianak by holding banner states that "We are kafir, this is our land and the kafir land, so do not come here". This sentence is an expression to resist his racism attitude toward minority in social media. ${ }^{4}$ They also demand the government to dissolve

${ }^{4}$ See https://nasional.tempo.co/read/835563/begini-penghadangan- 
FPI and other radical organization that was actively campaign for intolerant, violence, anti-Pancasila and anti-constitution of Indonesia. Jonru and Fakhri Hamzah also ignored by local community in their visit because of racism and brutal comment and hatred worldwide on social media. In his social activities in Sikka, Flores, East Nusa Tenggara Jonru aims to help poor people especially muallaf people (the new Muslim convertor), however local communities stop him and protest his attendance following his discriminative comment in social media. Fakhri Hamzah, PKS politician also was refused in Manado by a hundred people who are disappointed to his political attitude. The airport was surrounded to look for him and push him to return to Jakarta. The protestors yell at him said that no place for provocative people in Manado land. The police evacuated Hamzah from mass attack and take him to the event he has to present. However, Hamzah decides to return before the event close to anticipate the next demonstration. ${ }^{5}$

The female doctor Fiera Lovita from Solok, West Sumatra identified as Ahoker updated a new status on her Facebook making comment about sex scandal of the great Imam, Habib Rizieq. As soon as possible FPI militias come to her house and intimidate her through verbal violence demanding official sorry for what she said in her Facebook. After negotiation with FPI members, she was asked for writing an official letter for saying sorry and regrets comment and never repeats it again. FPI members in West Sumatera will take action until she acknowledged her mistake and write special letter. Even she wrote a letter FPI members are not satisfied and still intimidate her by spreading agitation on Facebook accused her deliberately insulting ulame and Islam. She was suffered from this event and asks mutation to another place to save her children from mental damage. Another persecution on video circulates in YuTube, where a teenager has been tortured by FPI members after defamation FPI top leader about his porn chat scandal. Five members from FPI have done serious interrogation and strike his face and shake his head. They guide him to say sorry for what he was done and never repeat it again. This interrogation takes place in the middle of the night by aggressive and violence approach under recorded camera. His mother just surrenders watching this event and unable to protect her son. However, the police quickly remove him and arrest those FPI members charged for child violence.

Those mentioned events show that Indonesian democracy and freedom are on threaten as the result of religious and ethnic interfering in the politics realm.

mui-dan-fpi-oleh-warga-dayak-di-sintang, January 15, 2017.

${ }^{5}$ https://regional.kompas.com/read/2017/05/14/08135951/kenapa. fahri.hamzah.ditolak.di.manado, Mei 15, 2017. 
The conflict identities have injured the values of Indonesian democracy by polarization of Indonesian citizen base on religious and ethnic orientation. It is the biggest challenges of Indonesian current democracy, where the Islamist put identities in conflict and violates the Indonesian constitution of Pancasila in such all citizens are equal in allover spaces. Islam and Pancasila have a strong connection and can stand side by side without withdrawing one and another. However, The Islamist groups still imagine replacing Pancasila by Islamic syariah through upholding Islamic State as the best solution for Indonesian problems of nationhood. The strength of Islamist political movements after Ahok defeat in Jakarta's election is the signal of the serious threat of Indonesian future of democracy where they are not only voices an Islamic syariah, but also attacking the minority group in politics rights.

\section{CONCLUSION}

The conflict of identities among Indonesians d has become stronger after Ahok was charged a penalty for two years detained related to his formal speech in Kepulauan Seribu mentioned al-Maidah 51 as a tool for political conspiracy to defeat minority candidate. For some Muslims the critic is normal but for some other groups they would understand that the critic is a form of blasphemy to Islamic symbol and ulame. Ahok is accused for taking too far the sacred text in which it is not his domain as non-Muslim, even though his reason to do it is as a reaction to high pressure from Islamist group by carrying this verse. Ahok defends himself with say no intention to blaspheme Islamic symbol, just to remind Muslim politicians that they should play fairly and not to use religious symbol for political interests.

Al-Maidah 51 is a potential verse to be politicized by Muslim politicians in each election moment especially contested to non-Muslim candidate. It happens in regional election of Jakarta 2017 where Ahok is political enemy for conservative Muslim politicians. Previously, this verse was also used by politician in regional election of Bangka Belitung 2007 when Ahok became candidate from a minority group. So, it is difficult to conclude that this case is purely blasphemy on Islamic symbol and insult ulame because of the subjectivity to interpret the phenomenon. This case cannot be separated from the political context where there are groups of fundamentalist Muslims disagree to a leadership position of non-Muslim in the community of Islamic as majority. If they are consistent to this attitude, they should apply al-Maidah 51 in another region, not only in Jakarata.

The interpretations about al-Maidah 51 show the plurality and diversity of understanding of its content and context. The central debate is on the meaning 
of "auliya" word that influence to social-political practice. Some scholars give a meaning of auliya as close friend and alliance, and some mean it as leader. But the majority of scholars understand auliya as a close friend or alliance. In Indonesian context the basic question is how is al-Maidah 51 compatible with Indonesian constitution and democracy system that guarantees to everyone has equal right to vote and be voted? This verse is easy to use for personal and group political interests in the name of Islam. It is wise to conclude that Indomesian Muslims need to re-contextualize it to be more suitable with Indonesian constitution and democracy system.

\section{BIBLIOGRAPHY}

Aspinall, E. (2005). Opposing Suharto: Compromise, Resistance, and Regime Change in Indonesia. California: Stanford University Press

Bawazir, T. (2015). Jalan Tengah Demokrasi: Antara Fundamentalisme dan Sekularisme. Jakarta Timur: Pustaka Al-Kautsar.

Buehler, M. (2009). Islam and Democracy in Indonesia. Insight Turkey. Vol. 11(4): 51-63

Council of Europe. (2010). Blasphemy, Insult and Hatred: Finding Answers in a Democratic Society. Strasbourg Cedex: Council of Europe Publishing.

Crouch, M. (2012). Indonesia’s Blasphemy Law: Bleak Outlook for Minority Religions, Asia Pacific Bulletin, (146).

Effendy, B. (2003). Islam and the State in Indonesia. Pasir Panjang: Iseas.

Ernas, S. (2016). Architecture of Peace in Ambon: Reading Dynamics of Peace After Ten Years of Conflict. Al-Albab, 5(2), 219 - 236. doi:https://doi. org/10.24260/alalbab.v5i2.504

Gubo, D. T., (2015). Blasphemy And Defamation of Religions In a Polarized World: How Religious. London: Lexinton Books.

Ginting, J. (et.al). (2008). Merubah Indonesia: The Sory of Basuki Tjahaja Purnama. Jakarta: The Center for Democracy and Transparency.

GLRC. (2017). Blasphemy and Related Laws in Selected Jurisdictions, The Law Library of Congress.

Hadiz, V. R. (2017). Indonesia's Year of Democratic Setbacks : Towards a new Phase of Deepening Illiberalism. Bulletin of Indonesian Economic Studies, Vol. 53 (3): 261-78 
Hamdi, S., Carnegie, P. J., \& Smith, B. J. (2015). The Recovery of a non-violent Identity for an Islamist Pesantren in an Age of Terror. Australian Journal of International http://dx.doi.org/10.1080/10357718.2015.1058339

Hamdi, S. (2011). Ahmadiyah di Era Reformasi. Jurnal Al- Ulum, Vol. 11 (1):27-46.

----.. (2012). Indonesian Politics in 2012 : Coalitions, Accountability and the Future of Democracy. Bulletin of Indonesian Economic Studies, Vol. 48 (3): $325-45$.

Lindgren, T. (2017). The Psychological Study of Religious Violence: A Theoretical and Methodological Discussion. Al-Albab, 5(2), 157 - 176. doi:https://doi.org/10.24260/alalbab.v5i2.471

Miichi, K. (2006). "Penetration of moderate Islamism in contemporary Indonesia, in Masatoshi Kisaichi, Popular Movements and Democratization in the Islamic World. New York: Routledge.

Lim, M. (2017). Freedom to Hate : Social Media, Algorithmic Enclaves, and the Rise of Tribal Nationalism in Indonesia. Critical Asian Studies, https://doi.org/10.1080/14672715.2017.1341188

Mulyadi, (2016). Ahok: Simbol Anomali Bahasa Kelas Penguasa. OKARA Journal of Languages and Literature, Vol. II(5):123-134.

Platzdasch, B. (2009). Islamism in Indonesia: Politics in the Emerging Democracy. Pasar Panjang: Iseas

Prasetyo, D. (2014). Persepsi Masyakarat DKI Jakarta Terhadap Figur Dan Komunikasi Politik Basuki Tjahaja Purnama (Ahok), Politika, Vol.5(2).

Prasojo, Z.H. (2017). Social Change and the Contributions of the Tionghoa, Dayak and Melayu (Tidayu) in West Kalimantan. In: King V., Ibrahim Z., Hassan N. (eds) Borneo Studies in History, Society and Culture. Asia in Transition, vol 4. Springer, Singapore

Rumahuru, Y. (2016). Socio-Religious Movement of Religious Affiliated Student Organizations After Social Conflict in Ambon. Al-Albab, 5(2), 251 - 264. doi:https://doi.org/10.24260/alalbab.v5i2.505 